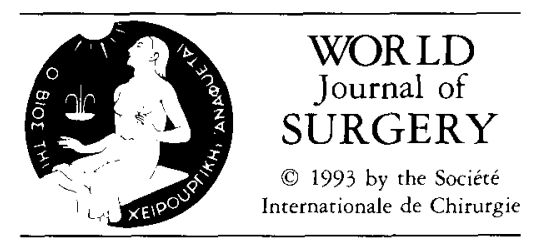

\title{
Gastroschisis and Omphalocele
}

\author{
Jan C. Molenaar, M.D. and Dick Tibboel, M.D. \\ Department of Pediatric Surgery, Sophia Children's University Hospital, Erasmus University, Rotterdam, The Netherlands
}

It has been widely acknowledged that exomphalos and gastroschisis are two different clinical entities. Their etiology and pathogenesis, however, remain controversial. Several techniques are available for making a prenatal diagnosis of these as well as many other malformations. Some prenatal treatment is possible, but operative management is the more usual course. In most cases, of omphalocele and gastroschisis, treated either conservatively or by any kind of surgery, intensive care is mandatory to support nutrition and often ventilation as well. Enteral nutrition at an early stage during the postoperative period might lead to bouts of necrotizing enterocolitis requiring aggressive medical treatment and sometimes even operative treatment.

It has been widely acknowledged that exomphalos and gastroschisis are two different clinical entities (Table 1; Figs. 1 and 2). Their etiology and pathogenesis, however, remain controversial.

\section{Etiology and Pathogenesis}

Duhamel explained the differences in appearance from the point of view of different embryologic origins [1]: (1) Omphaloceles are the result of an "inborn error" in fetal morphogenesis and are in fact monstrosities, which is why they, like all other monstrosities, are often accompanied by other congenital malformations. (2) Gastroschisis, on the other hand, is caused by a teratogenic agent during the development of the embryo; it is not a monstrosity and is rarely associated with other than local congenital lesions.

Shaw did not believe in "gastroschisis" as a separate pathologic entity [2]. In his opinion, gastroschisis is "simply a hernia of the umbilical cord that ruptured after completion of the infolding of the somatic components of the anterior abdominal wall, but before closure of the umbilical ring." The abdominal evisceration is due to rupture of the umbilical membrane during a normal embryologic phase and not to a teratologic insult, as is probably the case for omphalocele. Therefore the incidence of nongastrointestinal anomalies is low.

The lesion that initiates the development of omphalocele or gastroschisis is entirely unknown. Hoyme and coworkers sug-

Reprint requests: J.C. Molenaar, M.D., Department of Pediatric Surgery, Sophia Children's Hospital, P.O. Box 70029, 3000 LL Rotterdam, The Netherlands. gested that gastroschisis is caused by premature regression of one of the two omphalomesenteric arteries connecting the yolk sac with the dorsal aorta during the earliest embryonic phase [3]. Such premature regression might lead to ischemic changes of the developing abdominal wall. From studies in normal human embryos it is generally assumed that gastroschisis occurs early in the embryonic phase, probably between the 5 th and 8 th weeks of gestation [4, 5]. Investigations in human embryos and fetuses with gastroschisis confirm this assumption [6].

There are no developmental data that might explain the differences between the anatomic features of omphalocele and gastroschisis. Antenatal rupture of omphalocele is usually suggested as an explanation for gastroschisis [2]. This assumption is in agreement with rather late events during fetal life. Shaw's postulation therefore is not in agreement with early human fetal specimens of gastroschisis (Fig. 3) or with reports in the literature of prenatal diagnosis of gastroschisis with extracorporeal liver [7]. Kirk and Wah's series show a high percentage of extracorporeal livers (12/74) in infants born with gastroschisis [7].

Whatever the embryologic truth might be, it is a fact that the prognosis of children suffering from gastroschisis is definitely better than that of children suffering from omphaloceles. It is mainly due to a higher incidence of congenital anomalies in patients born with omphalocele. Moreover, the incidence of other congenital anomalies in the families of children born with an omphalocele is strikingly higher than that in the families of children born with gastroschisis [8].

More is known about the pathogenesis of the typical features of gastroschisis. The development of gastroschisis has been studied experimentally as well as clinically, particularly with regard to the characteristic fibrous coating of the protruding bowel loops, associated intestinal atresia, and postoperative hypoperistalsis without intestinal obstruction. Experimental investigation has been carried out in the chicken embryo and other animal fetuses. Clinical studies have been done in patients with gastroschisis, and some patients were followed prenatally.

The fibrous coating of the protruding bowel loops appears to be a late occurrence, directly related to changes of the amniotic fluid secondary to the onset of renal function. Associated intestinal atresia and postoperative hypoperistalsis in the absence of an obstruction appear to be due to another late 

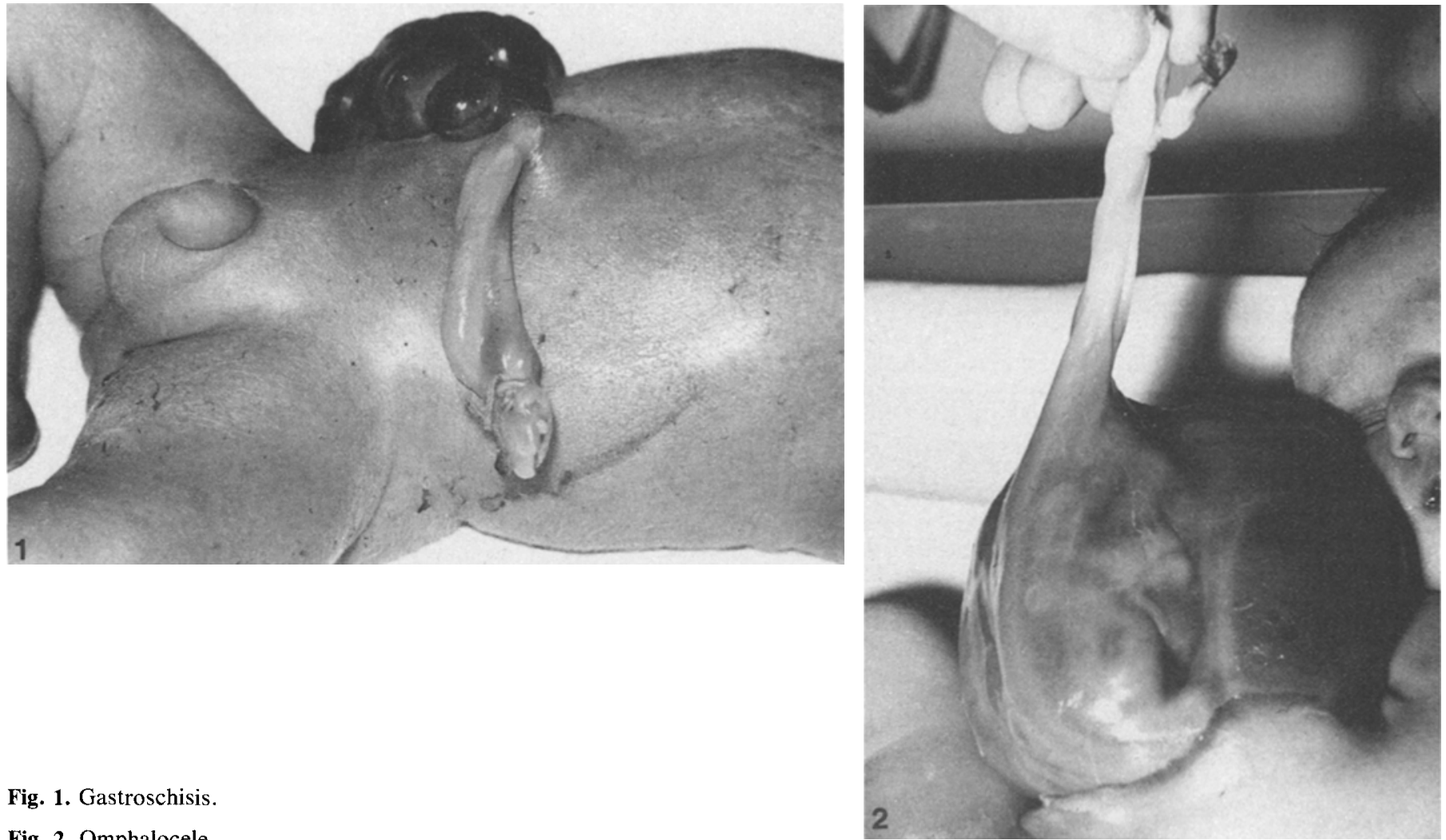

Fig. 2. Omphalocele.

weeks of gestation. The presence of abdominal viscera in the

Table 1. Gastroschisis versus omphalocele.

\begin{tabular}{lll}
\hline Parameter & Gastroschisis & Omphalocele \\
\hline $\begin{array}{l}\text { Size of defect } \\
\text { Contents }\end{array}$ & $\begin{array}{c}\text { Small } \\
\text { Bowel (no liver, } \\
\text { spleen) } \\
\text { Absent }\end{array}$ & $\begin{array}{c}\text { Small or large } \\
\text { Bowel } \pm \text { liver, } \\
\text { spleen }\end{array}$ \\
$\begin{array}{l}\text { Present (unless } \\
\text { avulsion) } \\
\text { Inflammation }\end{array}$ & Present & $\begin{array}{c}\text { Absent (unless } \\
\text { rupture) }\end{array}$ \\
$\begin{array}{l}\text { Umbilicus } \\
\text { Associated congenital } \\
\text { anomalies }\end{array}$ & $\begin{array}{c}\text { Adjacent insertion } \\
\text { Unusual (small } \\
\text { bowel atresias) }\end{array}$ & $\begin{array}{c}\text { Frequent } \\
\text { (cardiac } \\
\text { defects) }\end{array}$ \\
$\begin{array}{c}\text { Positive family } \\
\text { history }\end{array}$ & Unusual & Frequent \\
\hline
\end{tabular}

gestational event, consisting in ischemic changes of the bowel wall secondary to the compression of bowel loops and mesentery in the small-abdominal wall defect [9, 10]. Haller and coworkers suggested that the delayed onset of peristalsis that complicates the postoperative course of some gastroschisis patients might be the result of impairment of the enteric nervous system [11]. Others, however, could not substantiate this premise $[12,13]$.

\section{Prenatal Diagnosis}

Real-time ultrasound techniques enable observation of fetal normal anatomy and dynamics as early as the 10th to 12 th base of the umbilical cord is the diagnostic echographic characteristic of omphalocele. With present-day real-time scanners a diagnosis can be made as early as the 13th week of gestation. Many reports have emphasized the diagnostic role of fet protein concentration in amniotic fluid, although occasionally normal values are found. Furthermore, elevated fetoprotein levels may also be associated with other congenital lesions, such as open neural tube defects, intrauterine death, duodenal atresia, congenital nephrosis, and Turner syndrome. The risk of associated anomalies is great; figures range from $40 \%$ to $70 \%$ [14]. Associated defects are often severe, with chromosomal and cardiac abnormalities predominant. In our study of 46 cases over a 10-year period (1970-1980), the incidence of these abnormalities was $11 \%$ and $25 \%$, respectively [15].

Other frequent anomalies are craniofacial, gastrointestinal, and genitourinary tract malformations [14]. The overall mortality rate associated with the occurrence of an omphalocele has been reported to range from $30 \%$ to $45 \%$. In our study of 46 cases the mortality rate based on life-threatening anomalies was calculated to be as high as $80 \%$, whereas without life-threatening anomalies a rate as low as $16 \%$ was found. Accordingly, the outcome of fetuses with an omphalocele is not related to the omphalocele as such but, rather, to the presence of major associated anomalies.

Prematurity is another problem related to the omphalocele; the incidence is estimated to range from $10 \%$ to $25 \%$. From the literature it appears that prevention of rupture of the sac and exact timing of delivery to ensure immediate neonatal and 


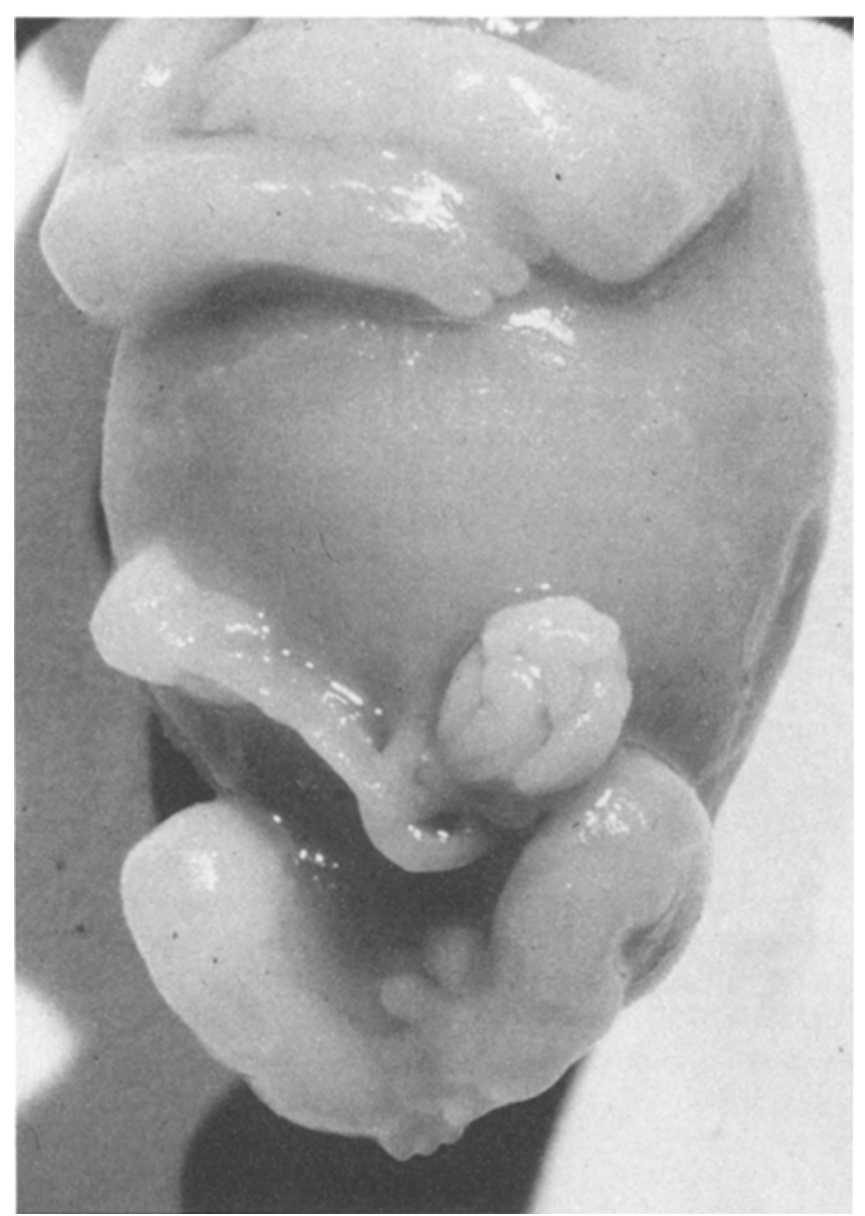

Fig. 3. Typical features of gastroschisis in a fetus with a gestational age of approximately 18 weeks.

pediatric surgical action are the main reasons for operative delivery. However, in 46 infants with unsuspected omphalocele who were delivered vaginally elsewhere and subsequently referred to the Sophia Children's Hospital for surgical correction, no sac rupture was observed.

It is usually possible to distinguish omphalocele from gastroschisis prenatally by visualizing the membranous sac that covers the herniated viscera. With gastroschisis, usually no other congenital abnormalities can be detected other than an occasional intestinal atresia. Therefore the overall mortality of about $10 \%$ is so much lower than with omphalocele. Prenatal sonograms often show dilated bowel loops and thickening of the bowel wall.

\section{Prenatal Management}

Prenatal management has been carefully mapped out by Harrison and Langer [16] and is shown in Figure 4. There are no clear indications for elective preterm cesarean section merely because of the existence of omphalocele or gastroschisis. Moore, in agreement with others, stated that the operative management of gastroschisis is greatly simplified when ultrasound detection of gastroschisis prior to bowel thickening is followed by pre- term cesarean section [17]. There is no evidence, however, that this method improves the final outcome.

Although most studies have failed to demonstrate the advantage of cesarean section over vaginal delivery, there seems to be a predilection among obstetricians to do a cesarean section after the diagnosis of gastroschisis or omphalocele has been confirmed prenatally.

\section{Operative and Postoperative Management}

\section{Omphalocele}

There is no consensus about the optimal treatment of large, unruptured omphaloceles. Various types of treatment are available, including nonoperative methods such as the use of escharotics, biologic dressings, or polymer films, and operative methods such as skin flap closure or the use of prosthetic sheets. Generally various methods of treatment in a nonrandomized manner are reported for one and the same series, but the more critically ill patients usually undergo nonoperative treatment.

There is no doubt that small defects can be closed surgically. Religation of the umbilical cord after reduction of the hernial sac content should be avoided because of the risk that an open omphaloenteric duct or some other part of the bowel is included in the ligature.

Conservative treatment for large omphaloceles containing a large part of the liver is recommended for various reasons [18]. Conservative treatment gains time to diagnose other presenting congenital anomalies that may be difficult to diagnose in detail immediately after birth. Moreover, there is no danger of caval vein obstruction related to direct surgical closure. Septicemia is a rare complication of conservative treatment and is more often related to surgical closure using a Silastic sac or other bowel wall protheses. In case of ruptured omphalocele, the lacerations can usually be closed with a few continuous sutures.

During the first years of our practice omphaloceles were painted with mercurochrome, a treatment introduced by Grob in 1963 [19]. After publication of reports on mercury intoxications associated with this type of treatment, mercurochrome painting was replaced by daily application of an antibiotic powder (neomycin $3.3 \mathrm{mg}$ and bacitracin 250 units/g powder). In addition, the omphalocele is bandaged and suspended from the roof of the incubator to provide stabilization of the omphalocele and to prevent excessive pressure on the abdomen. Reconstruction of the abdominal wall is postponed until after the age of 1 year.

In one study, conservative treatment of major omphaloceles using daily topical application of silver sulfadiazine (a nontoxic local antibiotic) and delayed surgical closure were well tolerated and did not result in prolonged hospitalization [20]. Primary surgical closure (fascial closure, skin closure, or silo implant) however, was associated with local and general complications, such as wound infection, wound dehiscence, and systemic sepsis.

Good results of primary surgical closure, however, have been reported from the use of dura [21]. Even better results were obtained by amnion inversion repair $[22,23]$. This method is characterized by suturing a Silastic silo, without dissection of the skin and without removal of the amniotic membranes, 


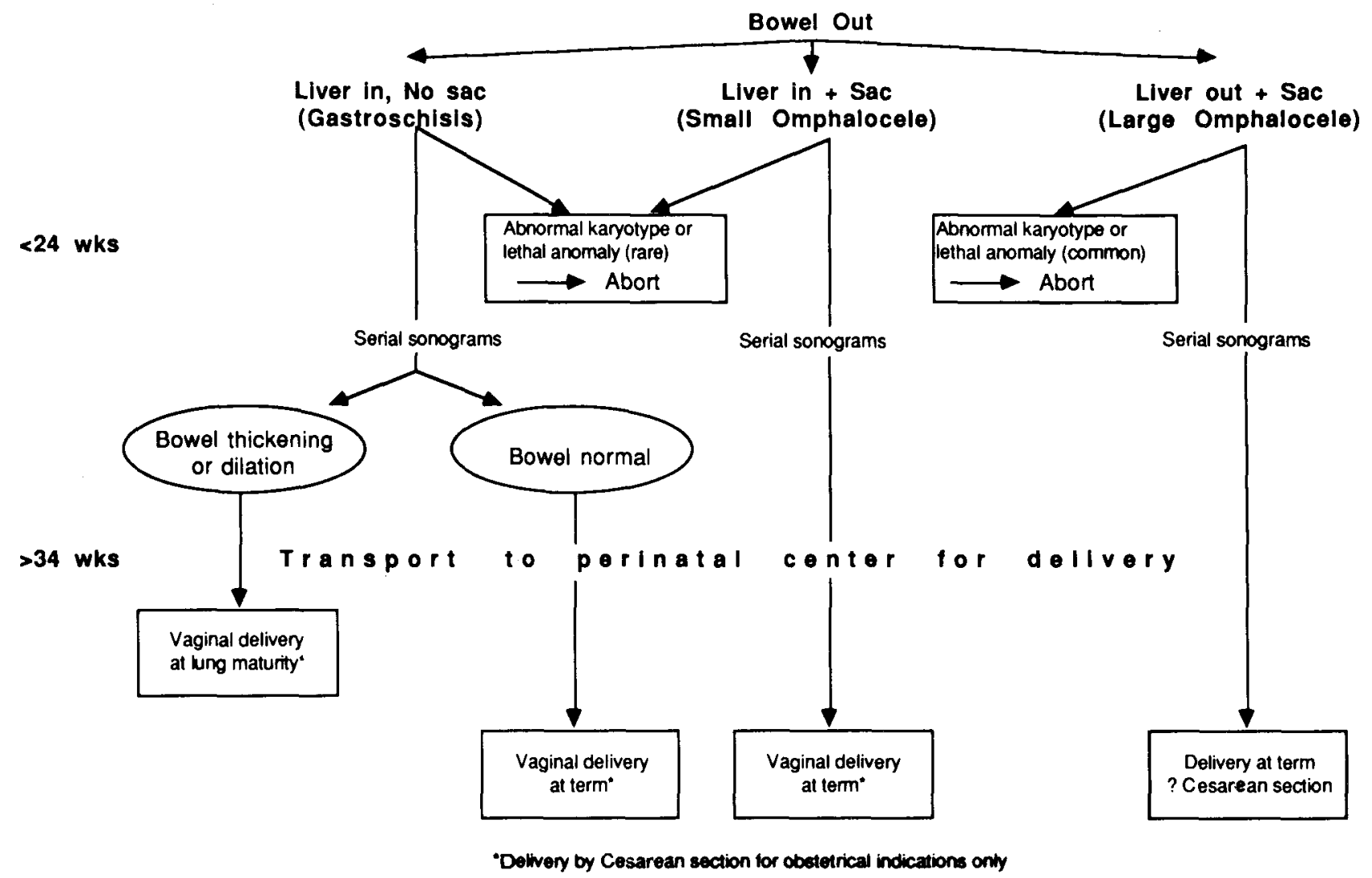

Fig. 4. Current approach to the management of the fetus with an abdominal wall defect. (Reprinted with permission of the publisher.)

directly to the skin around the omphalocele. By squeezing the Silastic silo the omphalocele can be reduced within about a week's time. After removing the silo the remains of the amniotic membranes are buried under the abdominal wall suture line.

\section{Gastroschisis}

It is beyond doubt that the prognosis of gastroschisis has improved dramatically in connection with better perioperative care. Thanks to improved transport facilities, which encompass life-sustaining aids, neonates with life-threatening congenital anomalies can be moved quickly and safely to appropriate centers. Parenteral nutrition, sepsis monitoring, and postoperative ventilatory assistance have extended the surgical possibilities. Consequently, surgical therapy can now be tailored more readily to the individual patient's needs.

In our experience gastroschisis is best treated by direct full-layer closure of the abdominal wall defect. A preoperative Gastrografin enema to empty the bowel may be helpful in this respect. If the extruded viscera cannot be repositioned initially, closure of the defect by means of a Silastic sac seems to be a reasonably good alternative, although it may result in greater, potentially dangerous morbidity due to septicemia. The ultimate prognosis of gastroschisis, however, depends on the presence or absence of an associated anatomic interruption of the gastrointestinal tract rather than on the method of surgical closure of the abdominal wall defect [24].
In a few patients with gastroschisis, the matted, leathery, opaque appearance of the intestine makes identification of bowel loops nearly impossible. In view of apparently poor vascularity of this protruding unidentifiable pieces of intestine, the surgeon is often tempted to resect them. They may, however, contain the larger part of the available bowel, which becomes visible if one allows a sufficient recovery period for the abdominal cavity after proper reduction and surgical closure of the abdominal wall [25]. A serious short-bowel syndrome can thus be prevented.

More often than not direct surgical closure of either omphalocele or gastroschisis leads to artificial ventilation. Schuster propagated closure with inert and impervious material, out of which he constructed a sac with which the intestines were covered [26]. This sac was sutured to the abdominal fascia and covered with antiseptic dressing (Betadine, Furacin). Maintaining slight pressure, the contents were gradually squeezed back into the abdomen; and after 8 to 10 days the sac was reduced to the level of the abdominal wall, after which closure of the defect could be attempted. Schuster's technique was aimed at repairing large omphaloceles, but now it is more frequently being applied in patients with gastroschisis.

\section{Postoperative Management}

In most cases of omphalocele and gastroschisis, treated either conservatively or by any kind of surgery, intensive care is mandatory to support nutrition and often ventilation as well. 
After conservative treatment of omphalocele the amniotic sac dries up and is gradually replaced by scar tissue. Because of contraction of the scar tissue the defect becomes smaller and is thus easier to close about a year after birth. In patients with gastroschisis, serious protein loss from the abnormal bowel wall is unavoidable, and protein should therefore be supplemented parenterally. Patients with gastroschisis often show impaired gastrointestinal dysmotility for which prolonged parenteral nutrition might be necessary. Enteral nutrition at an early stage during the postoperative period might lead to bouts of necrotizing enterocolitis requiring aggressive medical treatment and sometimes even operative treatment.

\section{Résumé}

Il est admis par presque tout le monde que l'omphalocèle et le gastroschisis sont deux entités différentes. Leurs étiologies, et leur pathogénies, cependant, restent controversées. Quel que soit l'agent étiologique ou les lésions qui sont à l'origine des ces malformations, le pronostic $\mathrm{du}$ gastroschisis est nettement meilleur que celui de l'omphalocèle. Ceci est dû principalement à l'incidence plus élevée de l'association d'autres malformations congéntiales avec ce dernier. La mortalité globale est entre 30 et $45 \%$. Avec les techniques modernes d'échographie, le diagnostic prénatal peut être fait dès la 10è ou la 12è semaine de la gestation. La présence de viscères abdominaux à la base du cordon ombilical est un charactéristic diagnostique de l'omphalocèle. Cependant, même si des études n'ont pas démontré l'avantage de la césarienne sur l'accouchement par les voies naturelles, la plupart des obstétriciens semblent préférer la première solution dès lors que le diagnostic d'omphalocèle ou de gastroschisis est fait. Les détails de la technique chirurgicale dans chacune de ces entités sont données. Il faut y associer, en période postopératoire, une alimentation parentérale avec un excédent protéique.

\section{Resumen}

Hoy es generalmente reconocido que el onfalocele y la gastrosquisis son dos entidades clínicas diferentes. Sinembargo, persiste controversia en cuanto a su etiología y patogénesis. En este artículo se revisan las hipótesis sobre etiología y patogenesis, se describen las técnicas de diagnóstico prenatal de éstas y en otras malformaciones congénitas que pueden estar asociadas. También se discuten las diferentes opciones en el tratamiento quirúrgico del onfalocele y de la gastrosquisis, así como el manejo postoperatorio, el cual incluye cuidado intensivo con soporte nutricional y ventilatorio. Los pacientes con gastrosquisis con frecuencia exhiben dismotilidad gastrointestinal, por lo cual requieren nutrición parenteral prolongada. La nutrición enteral en las etapas precoces del período postoperatorio puede dar lugar a episodios de enterocolitis necrotizante que demanda tratamiento médico agresivo $\mathrm{y}$, en algunas ocasiones, intervención operatoria.

\section{References}

1. Duhamel, B.: Embryology of exomphalos and allied malformations. Arch. Dis. Child. 38:142, 1983

2. Shaw, A.: The myth of gastroschisis. J. Pediatr. Surg. 10:235, 1975

3. Hoyme, H.E., Higginbottom, M.C., Jones, K.L.: The vascular pathogenesis of gastroschisis. J. Pediatr. 98:228, 1981

4. Müntener, M.: Zur Genese der Omphalozele und Gastroschisis paraumbilikaler Bauchwanddefect. Z. Kinderchir. 8:380, 1970

5. De Vries, P.A.: The pathogenesis of gastroschisis and omphalocele. J. Pediatr. Surg. 15:245, 1980

6. Tibboel, D., Vermey-Keers, C., Klück, P., Gaillard, J.L.J., Koppenberg, J., Molenaar, J.C.: The natural history of gastroschisis during fetal life: development of the fibrous coating on the bowel loops. Teratology 33:267, 1986

7. Kirk, E.P., Wah, R.M.: Obstetric management of the fetus with omphalocele or gastroschisis: a review and report of one hundred twelve cases. Am. J. Obstet. Gynecol. 146:512, 1983

8. Noordijk, J.A., Bloemsma-Jonkman, F.: Gastroschisis no myth. J. Pediatr. Surg. 13:47, 1978

9. Tibboel, D., Raine, P., McNee, M., et al.: Developmental aspects of gastroschisis. J. Pediatr. Surg. 21:865, 1986

10. Klück, P., Tibboel, D., Van der Kamp, A.W.M., Molenaar, J.C.: The effect of fetal urine on the development of the bowel in gastroschisis. J. Pediatr. Surg. 18:47, 1983

11. Haller, J.A., Kehrer, B.H., Shaker, Y.: Studies on the pathophysiology of gastroschisis in fetal sheep. J. Pediatr. Surg. 9:627, 1974

12. Klück, P., Tibboel, D., Van der Kamp, A.W.M., Molenaar, J.C.: The autonomous innervation of the bowel in gastroschisis. Ann. Pediatr. Surg. $1: 117,1984$

13. Tibboel, D., Klück, P., Molenaar, J.C., Gaillard, J.L.J.: A comparative investigation of the bowel wall in gastroschisis and omphalocele. Pediatr. Pathol. 7:277, 1987

14. Irving, F.M., Rickham, P.P.: Umbilical abnormalities. In Neonatal Surgery, 2nd ed., P.P. Rickham, J. Lister, I.M. Irving, editors. Boston, Butterworths, 1978, pp. 313-316

15. Wladimirow, J.W., Molenaar, J.C., Niermeijer, M.F., Stewart, P.A., van Eyck, J.: Prenatal diagnosis and management of omphalocele. Eur. J. Obstet. Gynaecol. Reprod. Biol. 16:19, 1983

16. Harrison, M.R., Langer, R.: The fetus with an abdominal wall defect. In The Unborn Patient, M.R. Harrison, M.S. Golbus, R.A. Filly, editors. Philadelphia, Saunders, 1991, Ch. 38

17. Moore, T.C.: Elective preterm section for improved primary repair of gastroschisis. Pediatr. Surg. Int. 4:25, 1988

18. Bax, N.A.M., Mud, H.J., Noordijk, J.A., Molenaar, J.C.: A plea for conservative treatment of large, unruptured omphalocele. $\mathrm{Z}$. Kinderchir. 39:102, 1984

19. Grob, M.: Conservative treatment of exomphalos. Arch. Dis. Child. 38:148, 1963

20. Adam, A.S., Corbally, M.T., Fitzgerald, R.J.: Evaluation of conservative therapy for exomphalos. Surg. Gynecol. Obstet. 172:394, 1991

21. Klein, P., Hümmer, H.P., Wellert, S., Faber, Th.: Short-term and long-term problems after duraplastic enlargement of the anterior abdominal wall. Eur. J. Pediatr. Surg. 1:88, 1991

22. De Lorimier, A.A., Adzick, N.S., Harrison, M.R.: Amnion inversion in the treatment of giant omphalocele. J. Pediatr. Surg. 26:804, 1991

23. Yokomori, K., Olikura, M., Kitano, Y., Hori, T., Nakajo, T.: Advantages and pitfalls of amnion inversion repair for the treatment of large unruptured omphalocele: results of 22 cases. J. Pediatr. Surg. 27:882, 1992

24. Mud, H.J., Bax, N.M.A., Molenaar, J.C.: Gastroschisis: factors affecting prognosis. Z. Kinderchir. 32:214, 1981

25. Van Hoorn, W.A., Hazebroek, F.W.J., Molenaar, J.C.: Gastroschisis associated with atresia: a plea for delay in resection. $\mathrm{Z}$. Kinderchir. 40:368, 1985

26. Schuster, S.R.: A new method for staged repair of large omphaloceles. Surg. Gynecol. Obstet. 124:837, 1967 